\title{
TWO DIFFERENT MODES OF THE ORIGIN OF PLEISTOCENE PEDIMENTS: AN EXAMPLE FROM THE CENTRAL MORAVIAN CARPATHIANS, CZECH REPUBLIC
}

\author{
TADEÁŠ CZUDEK \\ Čapkova str. 19, 60200 Brno, Czech Republic \\ E-mail: tadeasczudek@volny.cz
}

\begin{abstract}
The Pleistocene soft rock pediments in the Central Moravian Carpathians developed due to different geomorphic processes. At a locality situated between Nesovice and Brankovice villages, it was mainly downwearing of the former river terrace and the underlying Lower Miocene strata due to development of a small flat, at present dry valleys (dells). At Slavkov u Brna (Austerlitz), in turn, the leading process affecting the same sediments as at the previous locality consisted in the recession of the northern valley side of the Litava River. The main reason for the development of the lower segment of the pediment at Slavkov u Brna in the contact zone with the Litava River terrace was surface runoff. The present appearance of the pediments at both localities is an effect of periglacial processes active in the Middle and mainly Late Pleistocene. Thus, the same landforms (pediments) developed in comparable geologic and climate conditions due to different processes caused by local geomorphic factors.
\end{abstract}

Key words: Pleistocene pediments, backwearing, downwearing, Central Moravian Carpathians, Czech Republic

\section{INTRODUCTION}

The Central Moravian Carpathians are situated in the SE part of the Czech Republic, east of the Brno town (Fig. 1). They are built up of folded Palaeogene strata of the flysch zone (clay, claystone, fine sand, sandstone and conglomerate) as well as Miocene marine strata (clay, fine sand, sporadic gravel and sandstone) of the Outer Western Carpathians and their foredeep basin. Quaternary sediments of the area have been described in detail by Zeman et al. (1980). The landscape is a dissected rolling country. Only in the NE part of the territory, in the Chriby Upland built up of resistant sandstone and conglomerate, a more dissected and higher topography does occur. The highest point of the foldfaulted area attains $587 \mathrm{~m}$ a.s.l. Pleistocene pediments have recently been investigated in the Litava River valley at two localities in the middle part of the Central Moravian Carpathians. The first site is situated between Nesovice and Brankovice villages, the second one at the town Slavkov u Brna (Fig. 1). Pleistocene soft rock pediments exist also in other places of the Central Moravian Carpathians (e.g., in the Trkmanka River valley, briefly described by Bubík and Švábenická, 2000). These features are well and widely developed also in the Dyjsko-svratecký úval Graben of the Carpathian Foredeep basin south of Brno (e.g., east of the town Židlochovice) and in the southernmost Moravia near the Czech Austrian border, NW of the town Mikulov. Pediments in the SW part in the Dolnomoravský úval Graben of the Vienna Basin were described by Czudek and Demek (1970), 


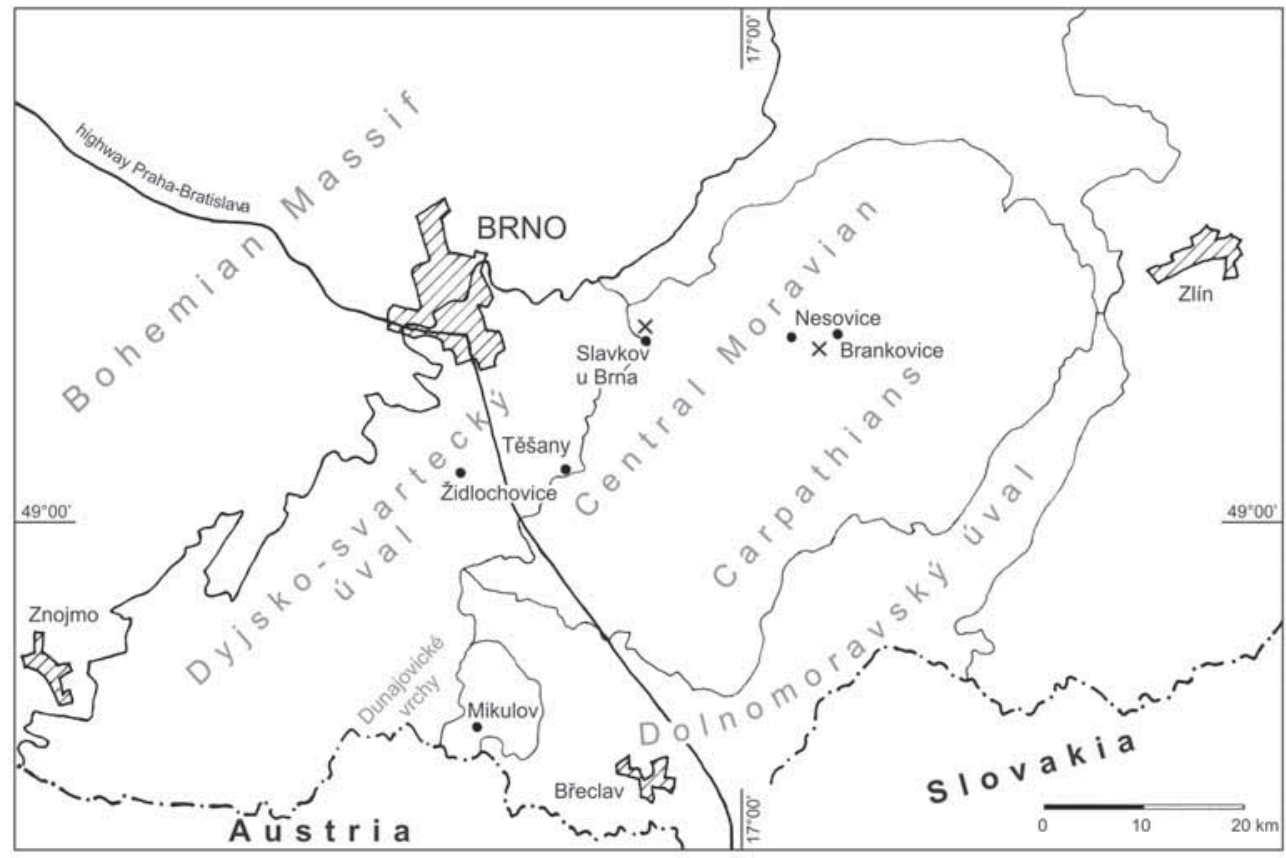

Figure 1. Localities (X) of the described Pleistocene pediments

Czudek (1988, 2005), and Vandenberghe and Czudek (2008). One should bear in mind that the Miocene soft rock territory of Southern Moravia is a classic Pleistocene pediment area. These low-angled surfaces (early described also e.g., by Dylik (1957) and Rotnicki (1974) from neighbouring Poland as well as by Brunotte and Garleff (1989) and Beck (1994) from Germany) occur there in lower position in respect to the highest Pleistocene river terrace and grade into lower terraces and/or directly to the valley bottom. However, it is not excluded that NW of the town Mikulov (in the Dunajovické vrchy Upland) and in the surroundings of the village Těšany at the foot of the marginal slope of the Central Moravian Carpathians, the pediments could have begun to develop as early as in the Late Tertiary.

\section{LOCALITY BETWEEN NESOVICE AND BRANKOVICE}

At the foot of the southern valley side of the Litava River between the villages Nesov- ice and Brankovice, a 2-km-long and 300 up to $470 \mathrm{~m}$ wide footslope surface occurs (Czudek, 2008). The area is built up of clay, claystone, fine sand and sandstone of the Ždánice Unit of the Carpathian flysch zone. Flat, small Pleistocene dry valleys, mostly up to $250 \mathrm{~m}$ wide and up to $8 \mathrm{~m}$ deep, divide the surface into five parts. For all of them geologic cross-sections were compiled (Fig. $2)$. These small valleys originate on the 40-60 $\mathrm{m}$ high and $12^{\circ}$ inclined backslope, which is underlain by the same flysch strata as the footslope surface. The footslope surface grades continuously northwards to the floodplain or to the low, 2-4 m high Holocene terrace of the Litava River at an angle $3-5^{\circ}$. Only in section 4 , a $17 \mathrm{~m}$ high and $8^{\circ}$ inclined slope does exist. Due to the presence of more resistant layer of sandstone, the footslope surface is at this place $8-10 \mathrm{~m}$ higher than the surrounding. The contact between the backslope and the footslope surface is well expressed.

Numerous boreholes and test pits indicated that outside the small, presently dry 


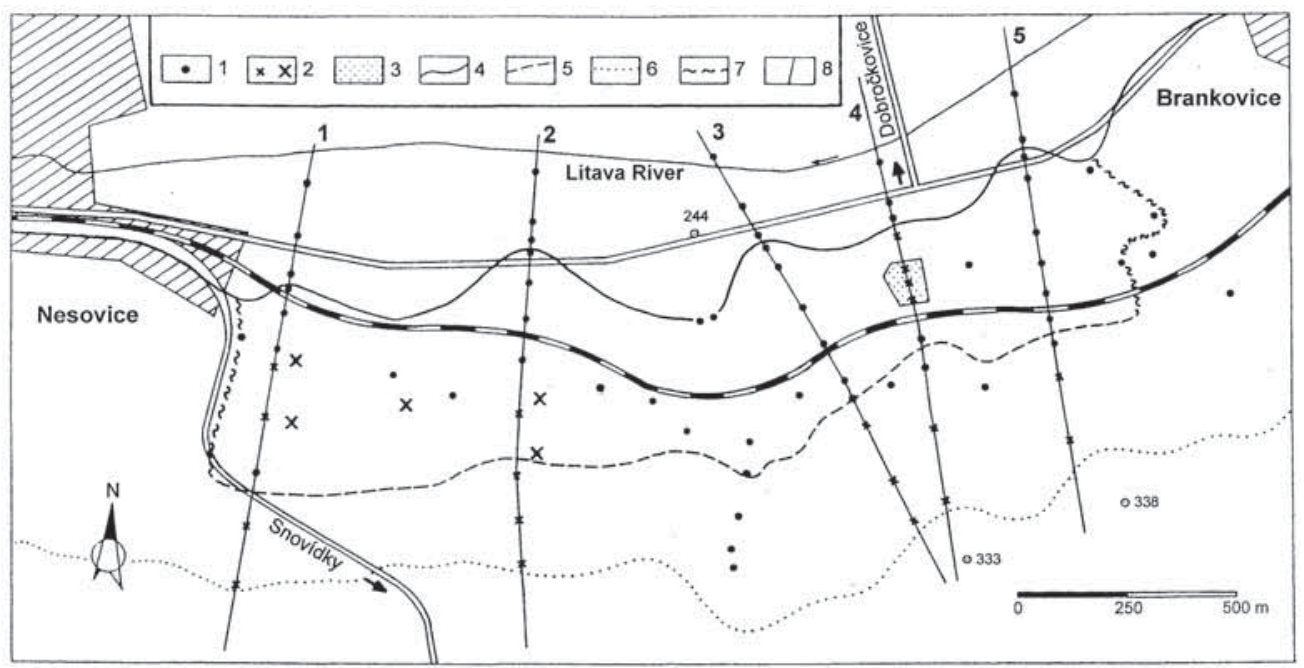

Figure 2. Map showing boreholes, test pits and boundaries of major landforms in the southern part of the Litava River valley between Nesovice and Brankovice villages

1 - boreholes, 2 - test pits and five up to $5.80 \mathrm{~m}$ deep excavations, 3 - area of fourteen shallow boreholes and three (2-3 m long) trenches, 4 - boundary between the Litava River floodplain and the Pleistocene pediment, 5 - boundary between the Pleistocene pediment and the backslope, 6 - upper edge of the backslope, 7 - western and eastern boundaries of the Pleistocene pediment, 8 - geological cross-sections.

valleys, the Quaternary regolith is up to $1.00-1.50 \mathrm{~m}$ thick, and in the scarp foot zone only $0.50-0.80 \mathrm{~m}$ thick. In the lowermost segment of the surface, in the area of transition to the low river terrace or floodplain, the thickness of waste material (clay, fine sand, loessial loam) is $4.00 \mathrm{~m}$ or so, while on the backslope it does not exceed $0.50 \mathrm{~m}$. Small thickness of Quaternary slope deposits, considerably lower gradient of the footslope surface than the folded sedimentary bedrock, and the presence of a remnant of the Middle Pleistocene fluvial gravels $(25 \mathrm{~m}$ above the river bed in a small area, up to $0.9 \mathrm{~m}$ thick), all indicate the erosional origin of the lowangled footslope surface, which represents a pediment (Figs. 3, 4).

The present-day altitudinal differences of the bedrock underlying Quaternary sediments indicate that the pediment surface is not the base of an older river terrace, but must have originated due to a few metres deep erosion after the removal of the terrace gravel. The main reason for such a downwearing can be seen at the intersection of neighbouring dell sides and, consequently, the unequal lowering of their interfluves due to gelifluction and sheet wash. One can conclude that at Nesovice - Brankovice only one pediment surface does exist, showing moderately differentiated relief. Thus, the pediment in the Litava River valley represents a surface postdating the 25-m-high fluvial terrace. Although the pre-existing landform of the footslope surface was the river terrace, the discussed pediment has now neither morphographic nor genetic relationship with it. Directly at the foot of the backslope zone (also in section 4), there are no traces of a former river terrace. This opinion is supported by boreholes and detailed field studies. Therefore, this part of the pediment must have developed due to recession of the southern side of the Litava River valley. The extent of the retreat is supposed to be up to about $100 \mathrm{~m}$. That is why the pediment at the locality Nesovice - Brankovice in the Central Moravian Carpathians can be considered as a composite pediment. It is the first example of such a type of relief feature in the Czech Republic, proved by borings and detailed geomorphic field work. 


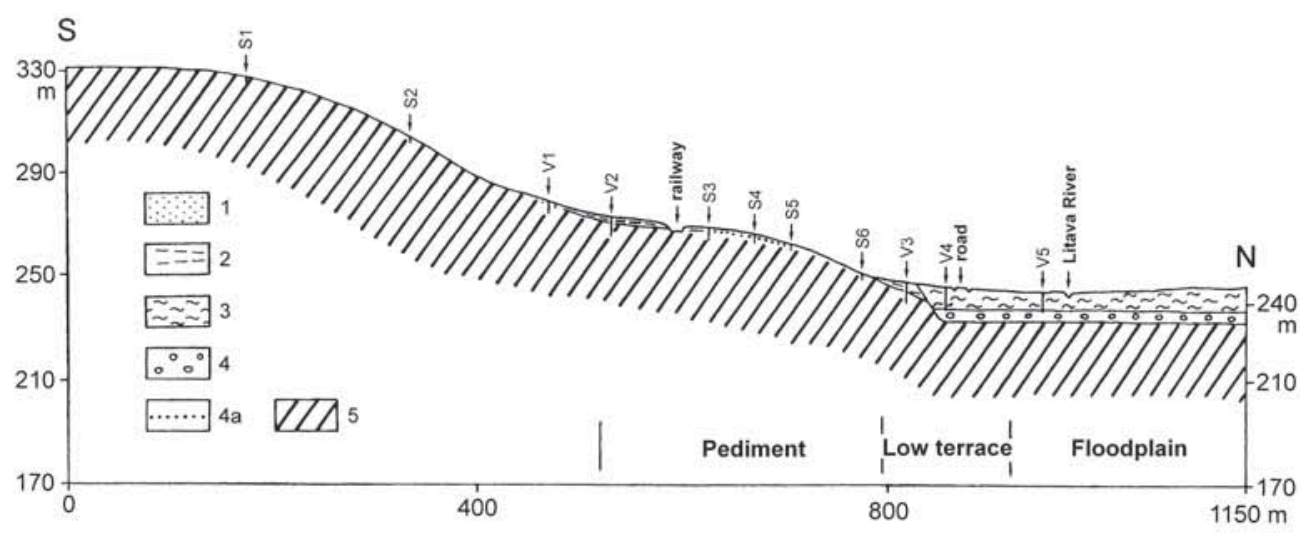

Figure 3. Pleistocene pediment in section 4 (see Figure 2) between villages Nesovice and Brankovice

1 - slope deposits (Holocene), 2 - slope deposits (mainly Upper Pleistocene), 3 - overbank deposits (Holocene), 4 gravel of the floodplain of the Litava River (Upper Pleistocene up to Holocene), $4 \mathrm{a}$ - relict of the terrace gravel (Middle Pleistocene), 5 - bedrock (folded clay, claystone and fine sand with sporadic sandstones of the Carpathian Flysch belt; Egerian). S1-S6 - test pits, V1-V5 - boreholes.

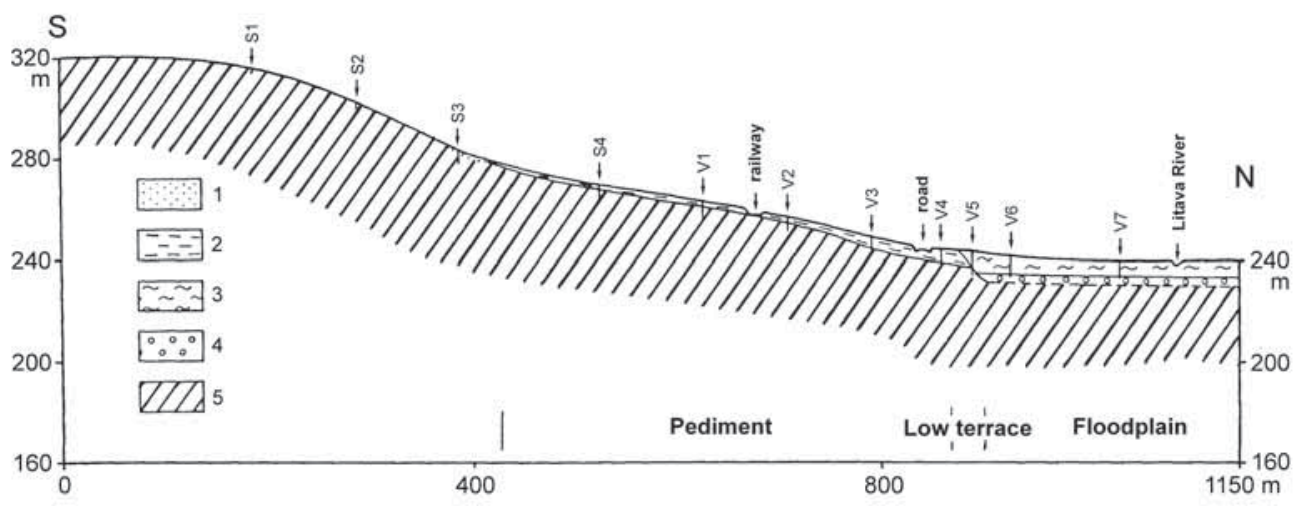

Figure 4. Pleistocene pediment in section 2 (see Figure 2) between villages Nesovice and Brankovice.

See Figure 3 for explanations

Since the present appearance of the composite pediment developed mainly due to destruction of the Middle Pleistocene river terrace, the origin of the pediment must have begun at the end of the Middle Pleistocene. Unlike the opinion of some authors (e.g., Büdel, 1977; French and Harry, 1992; French, 2007), the described pediment started to develop in the Pleistocene. In this case, this is not a "traditional development" from the Tertiary through the Quaternary.
Because cryogenic processes played a decisive role in the development of the pediment, it can be considered as a Pleistocene landform originated mainly in the Late Pleistocene. Nine boreholes drilled at the bottom of small flat dry valleys (dells) dissecting the pediment indicated as much as $2.40 \mathrm{~m}$ accumulation of present soil, while on the pediment surface outside the dells the soil is only $0.30-0.50 \mathrm{~m}$ thick. This is one of indicators that the pediments in agricultural 
areas of the Central Moravian Carpathians develop due to downwearing also at present. In short, the main period of such a development is that of snowmelt and frozen ground thawing during the winter-spring transition, as well as during heavy summer rainfalls.

\section{LOCALITY SLAVKOV U BRNA}

At the foot of the northern side of the Litava River valley at the town Slavkov u Brna (Austerlitz), there occurs a distinct low-angle footslope surface sloping southwards to the valley bottom (Fig. 5). The distance to the first described pediment between Nesovice and Brankovice villages attains $18 \mathrm{~km}$. The backslope and footslope surfaces at this locality are also underlain by soft strata (clay, fine sand and sporadic sandstone) of Early Miocene (Karpatian) age, of dips up to $35^{\circ}$. The footslope surface consists of two sections (Fig. 5). The inclination of the higher one, at the foot of the backslope, varies from $1^{\circ}$ to $7^{\circ}$. The lower section is inclined at $0.5^{\circ}-3.0^{\circ}$ (less than $1^{\circ}$ inclined softrock Quaternary pediments are known also from other countries - e.g., Rotnicki, 1974). The maximum width of the surface attains 1.0 $\mathrm{km}$, and its length from the west to the east is $2.5 \mathrm{~km}$. The junction between the upper segment of the footslope surface and the backslope is usually sharp, while that between the two parts of the surface is less expressive. The height differences at the contact between both parts of the footslope surface are up to $4-10 \mathrm{~m}$. The contact zone between the lower part of the footslope surface and the 4-6 $\mathrm{m}$ high terrace of the Litava River is occupied by mostly gentle, 1-2 m high slope. A short, only some hundreds of metres long and 5-15 m deep flat valleys of the Hangdellen type, and the main, 30-40 m deep valley along the road Slavkov u Brna - Rousínov, both dissecting the backslope, occur on the lower part on the footslope surface, as only 2-4 $\mathrm{m}$ deep and a few hundreds of metres wide flat dry dells. Numerous test pits, boreholes, and even about 100-m-long trenches indicated that the upper part of the footslope surface is covered by only $0.40-1.20 \mathrm{~m}$ thick waste material. However, in many places this material is completely absent and the Holocene soil is underlain directly by bedrock. A similar situation was also observed on the lower (younger) segment of the surface, although at the contact with the river terrace the slope deposits (clay, fine sand and loess-

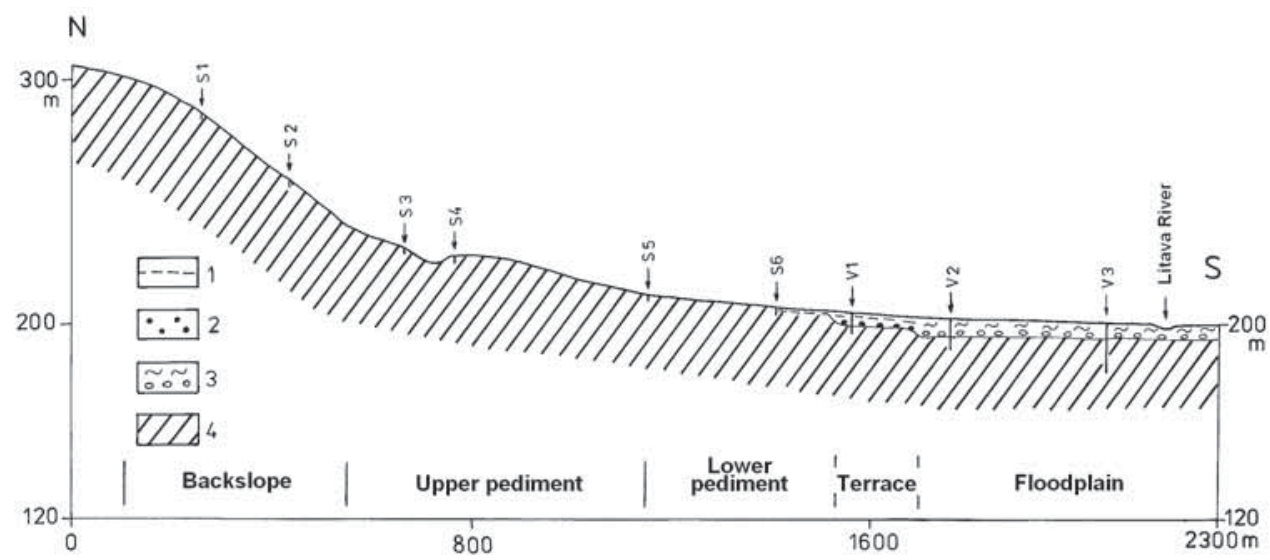

Figure 5. Pleistocene pediment at Slavkov u Brna (western part)

1 - slope deposits (Upper Pleistocene to Holocene), 2- gravel of the Upper Pleistocene fluvial terrace, 3 - overbank deposits (fine sand, clay, silt) and gravel of the floodplain of the Litava River (Upper Pleistocene to Holocene), 4 - bedrock (inclined clay, fine sand and sporadic sandstones; Lower Miocene, Karpatian). S1-S6 - test pits, V1-V3 - boreholes. 
ial loam) attain thicknesses of $2.00 \mathrm{~m}$ to 2.30 $\mathrm{m}$. This proves erosional origin of the footslope surface, i.e. the pediment.

The backslope is built up of the same rocks as the pediment and is as much as 40-60 m high, with an inclination of up to $10-14^{\circ}$. Besides the above mentioned flat dry valleys, traces of small landslides are also present on the slope. Quaternary sediments underlying the soil on the backslope are only $0.20-0.40 \mathrm{~m}$ thick.

As it was already mentioned, at Slavkov $\mathrm{u}$ Brna the pediment and the backslope are both underlain by Lower Miocene strata. There is no geologic or geomorphic evidence for tectonic subsidence at the foot of the backslope. Lateral erosion of the Litava River can be excluded as well. Hence, the available pieces of evidence suggest that the footslope surface developed as a pediment. The main reason for the backslope recession was the large number of small flat slope valleys (slope dells - Hangdellen). Geomorphic processes acting on the pediment included surface runoff, sheet wash and solifluction. The best conditions for such a development occurred, like at the first discussed locality Nesovice - Brankovice, between warm and cold phases of the periglacial climate, and especially between cold and warm climate periods when deep permafrost thawing and poor vegetation cover did prevail.

On one hand surface erosion of running water as well as gelifluction and sheet wash transported away the fine material derived from the backslope, and on the other hand they lowered the pediment surface. The most intensive transport of the material took place along the axes of flat valleys dissecting the backslope and the pediment. It can be concluded that while the recession of the backslope (the right side of the Litava River valley) led to formation of the pediment, the present-day shape of this surface must be attributed to the downwearing processes. The development of the lower section of the footslope, which formed on the upper (older) part of the surface, was caused by a climate change leading to higher humidity resulting in valley incision. Valleys incised into the pediment and surface runoff (overland flow) as a major process lowered the contact zone between the pediment and the river terrace and led to formation of the lower part of the pediment. The more precise age of this process can not be specify due to the lack of reliable terrace dating. One can only conclude that the footslope surface at Slavkov u Brna is considered to be a pediment developed mainly in cryogenic periods of the Late Pleistocene, in permafrost environment. The evolution of the pediment continues in a slower way also at present, both mainly during snowmelt and frozen ground thawing at the end of winter and the beginning of spring as well as during heavy summer rainfalls.

\section{CONCLUSIONS}

Pleistocene pediments developed on identical soft Lower Miocene strata originated at both described localities in the Central Moravian Carpathians due to different geomorphic processes. The major process which caused the origin of the pediment at the site between Nesovice and Brankovice villages was the downwearing of the $25 \mathrm{~m}$ high Middle Pleistocene river terrace and its bedrock due to the development of small shallow valleys of dells type, and - to a lesser extent - backslope recession. At Slavkov $\mathrm{u}$ Brna, the main process of pediment development consisted in backwearing of the northern side of the Litava River valley due to particularly common small slope dells. The lower, younger part of the pediment developed due to downwearing of the older pediment, particularly by surface runoff. It can be concluded that, in the Central Moravian Carpathians, the described pediments are considered to have developed mainly in warmer and wetter climate conditions during the Middle and especially Late Pleistocene, in permafrost environments. However, it can not be excluded that they were active also in the last interglacial time. All available pieces of evidence suggest that the pediments in agricultural environment of the Central Moravian Carpathians, like in the entire area of 
the Outer Western Carpathians in the Czech Republic, have been shaped continuously from the Pliocene to the Holocene.

\section{ACKNOWLEDGEMENTS}

The field work was partly facilitated by the Czech Scientific Foundation (project No. 205/08/0209). The paper benefited from useful comments by Professor W. Zuchiewicz as well as from the unknown reviewer.

\section{REFERENCES}

Bubík, M. and Švábenická, L. (2000), Nové poznatky o ždánické jednotce na listu 34-221 Kyjov získané během sezony 1999 [New informations on the Ždánice Unit on the map sheet 34-221 Kyjov obtained during field season 1999], Zprávy o geologických výzkumech v roce 1999: 10-12.

Beck, N. (1994), Reliefentwicklung im nördlichen Rheinhessen unter besonderer Berücksichtigung der periglazialen Glacis- Pedimentbildung [Development of the relief in northern Rheinhessen with special regard to periglacial glacis and pediment development], Forschungen zur Deutschen Landeskunde, 237: 1-175.

Brunotte, E. and Garleff, K. (1989), Structural landforms and planation surfaces in southern Lower Saxony, Catena Suppl., 15: 151-164.

Büdel, J. (1977), Klima-Geomorphologie. Gebrüder Borntraeger.

Czudek, T. (1988), Kryopedimente - wichtige Reliefformen der rezenten und pleistozänen Permafrostgebiete [Cryopediments - important relief forms in contemporary and Pleistocene permafrost environments], Petermanns Geographische Mitteilungen, 132: 161-173.
Czudek, T. (2005), Vývoj reliéfu krajiny České republiky v kvartéru [Quaternary development of landscape relief of the Czech Republic], Moravské zemské muzeum.

Czudek, T. (2008), Kryopediment v údolí Litavy východně od Bučovic, Středomoravské Karpaty [Cryopediment in the Litava River valley east of Bučovice, Central Moravian Carpathians], Geologické výzkumy na Moravěa ve Slezsku, 15: 8-12.

Czudek, T. and Demek, J. (1970), Pleistocene cryopediments in Czechoslovakia, Acta Geographica Lodziensia, 24: 101-108.

Dylik, J. (1957), Próba porównania powierzchni zrównań w warunkach półsuchych klimatów gorących i zimnych [Tentative comparison of planation surfaces occuring under warm and under semi-arid climate conditions], Biuletyn Peryglacjalny, 5: 37-49.

French, H.M. (2007), The periglacial environment, $3^{\text {rd }}$ Edition, John Wiley \& Sons, Ltd.

French, H.M. and Harry, D.G. (1992), Pediments and cold-climate conditions, Barn Mountains, unglaciated Northern Yukon, Canada, Geografiska Annaler, 74 A: 154-157.

Rotnicki, K. (1974), Slope development of Riss Glaciation end moraines during the Würm, its morphological and geological consequences, Quaestiones Geographicae, 1: 109-139.

Vandenberghe, J. and Czudek, T. (2008), Pleistocene cryopediments on variable terrain, Permafrost and Periglacial Processes, 19: 71-83.

Zeman, A., Havlíček, P., Minaříková, D., Růžička, M. and Fejfar, O. (1980), Kvartérní sedimenty střední Moravy [Quaternary sediments in central Moravia], Anthropozoikum, 13: 37-91.

Paper first received: April 2011

In final form: August 2011 